\title{
Using Accounting Perspectives and Financial Performance to Detect Fraudulent Financial Reporting
}

\author{
Jasmine Irishabel, Aqamal Haq, Murtanto* \\ Faculty of Economics and Business \\ Universitas Trisakti \\ Jakarta, Indonesia \\ *murtanto@trisakti.ac.id
}

\begin{abstract}
The aim of this study is to examine whether various accounting perspectives and financial ratios can be used in detecting fraudulent financial reporting among the Indonesian agricultural sector, starting the year 2013 to 2016. The accounting perspectives used include Going concern and audit quality while the financial ratios include: ROA, Gross Profit Margin, Inventory Turnover, Receivable turnover, total debts to total assets and the working capital. The study used a fixedeffects model with panel data to help identify all the variables that influence the detection of fraudulent financial reporting. The result show that using the $M$-score as the proxy, both independent and control variables do have a great influence over fraudulent financial reporting. The findings will have critical implications for investors in helping them make the accurate type of investment decisions.
\end{abstract}

Keywords-going concern, audit quality, m-score, agricultural sector, financial ratio, financial fraudulent reporting

\section{INTRODUCTION}

The incidence of fraud in any company will always receive a great deal of attention from the members of the public, auditors, regulators and stakeholders, and will often within the financial division of the company [1]. There are many factors that will lead to people to commit fraud, and the situation gets worse when the individual committing fraud belongs to the organization. This always happens in cases of abuse of authority and a weak supervision system [2]. However, there are many ways through which organizations can use to curb the incidences of fraud. For example, an organization can measure its financial performance using its financial ratio, which is critical in analyzing any financial statements published for users of financial statements and the public at large, making it easier for one to detect an intent to commit fraud by an organization or individual of the organization without even knowing the system that runs in the organization. There are five types of financial records. These include capital turnover, activity ratio, profitability ratio, leverage ratio and liquidity ratio.
When it comes to the leverage ratio, having a high level of leverage leads to a higher probability for the incidence of a foul on credit statements [3]. Additionally, there are cases whereby a manager can manipulate a company's profitability to paint a picture of financial stability and growth proxy [4]. In terms of the activity ratio, studies show that it is a key aspect of lawsuits lodged against companies committing fraudulent financial reporting due to misstatements in inventories and account receivables [5]. As for the capital turnover, it has been noted a lax sense of competition compared to managers responsible for non-fraud firms in generating sales [6]. Finally, this research uses the liquidity ratio to determine whether a firm can pay up its short term financial obligations and having a low liquidity ratio provides an avenue for managers and other business leaders to take part in fraudulent financial reporting $[7,8]$.

The study will also rely on the going concern opinion, audit quality and the audit report as indicators of whether managers are taking part in fraudulent financial reporting. There are a number of indicators that do point towards the direction of fraudulent financial reporting. Consider the case where an organization is audited by 4 of the big audit firms: Ernest \& Young, Deloitte [9] and price water [10], such an organization has a low incidence of fraudulent activities as it has a higher level of audit independence and quality. Different audit firms will offer different types of audit services [11], for example, a firm is more likely to get quality auditing when relying on larger audit firms since they have more expertise compared to their smaller competitors [12].

Large audit firms often deal with large companies drawn from different type of industries, which lead to enhanced auditor skills. Therefore, firms audited by small auditing firms will often be forced to work with low auditor skills, providing an avenue for committing fraudulent financial reporting. Additionally, it is important that the going concern of the auditor be examined using both stressed and non-stressed samples as there is a higher likelihood of fraud in bankrupt firms [13,14]. In support of this, a number of studies have 
shown that a struggling firm with a going concern has a higher chance of getting involved in fraudulent financial reporting [7].

\section{LITERATURE REVIEW}

The fraud triangle is made up of the fraud pentagon, which is made up of the elements of arrogance and competence. Competence is associated with the ability of an individual to override an advantageous situation while arrogance can be defined as an individual's attitude of greed, entitlement and superiority that makes him or her feel above the set policies and procedures [14-16].

The Big 4 audit firms, including Ernest and young, Delloite and Price water, can be used to determine audit quality $[9,10]$. Any firm audited by any of these big four firms have a lower likelihood of committing fraudulent financial reporting as these firms provide high-quality audit services and dominate the professional accounting services market [17]. With big audit firms, an organization is slated to gain key benefits and better services since the employees of the audit firm practice a higher level of specialization and the chance to continue with their professional education, and that the background of the audit team involved is extensive as they get to audit firms from different industries [12]. A previous study Hopwood [13] shows that an auditors' going concern decision should be tested using both non-stressed and stressed samples as there is a higher likelihood of bankrupt firms to engage in fraudulent financial reporting.

The tendency to engage in manipulation or commit financial fraud can be measured using Beneish M-Score, a mathematical model developed by Professor Messod Daniel Beneish [18]. The method comes with a variety of variables that are critical in helping identify any tendency of manipulation or the occurrence of fraud [18]. When using this model, a company is less likely to engage in fraud if scores an $\mathrm{M}$-score that is less than -2.22 . However, when the M-score is greater than -2.22 , there is a higher chance that the organization is taking part in fraudulent financial reporting. Using this model is useful to auditors in helping identify any areas of manipulation and potential manipulators. The study will rely on this model to help calculate the M-score of an organization to determine whether it is engaging in fraud [19].

A company's ability to meet its short-term financial obligation is measured using the liquidity ratio [7]. To obtain the ratio, the Working capital is divided by the Total Assets (WC/TA). When an organization has a lower liquidity levels, managers can see this as an opportunity to engage in various fraudulent activities [8]. Leverage, on the other hand, is measured by comparing the firm's total debts to its total assets (TD/TA). High leveraged companies risk falling into bankruptcy in the case that they cannot meet their financial obligations [20]. Having a high-debt structure increases the likelihood of fraud as the risk has been transferred from the mangers and equity owners to the debtors [20]. The variable associated with leverage is positive, meaning that higher leverage creates a high potential for fraud and other financial violations.

The activity ratio of a company is used to describe the company's activities that make running operations involved with purchases and sales among others and is measured by carrying out a comparison of the company's Receivable Turnover (RV/TA) and Inventory Turnover (IV/TA). A company's whose current assets is made up of account receivables and inventories has a higher likelihood of committing fraud. This is because a huge number of lawsuits regarding companies taking part in fraudulent financial reporting are caused by the misstatements of both inventories and account receivables [5]. This variable is positive, indicating that having a higher level of both items will increase the risk of overstatements, increasing the likelihood of fraud.

A company's profitability can be measured using the Return on asset (NI/TA) and Gross profit margin (COGS/REV). Firms that often record lower levels of profit provide their managers with an incentive to overstate figures related to expenses or revenue in the expectation of increasing the company's value profitability, which instead, leads to significant financial statement errors [21]. The variables for this factor are negative as a motivation for fraudulent financial reporting is fuelled by results not matching the actual performance.

A key study argues that a higher level of audit quality is experienced in larger and longer audit firms as they practice great levels of independence since a single client remains immaterial to the firm's audit practice [11]. And therefore, any company that is audited by any of the big 4 auditors will have a lower incidence of fraud compared to firms audited by the nonbig 4 auditors, showing the positive effect that the quality of an audit is likely to have in reducing the likelihood of fraudulent financial reporting in an organization.

When testing the going concern of an auditor slated to carry out an audit, it is important that both stressed and non-stressed samples be used [13]. This is because of the potential of firms engaging in fraud. It is expected that all the firms in this research with a going concern will likely commit fraud in a bid to free itself from bankruptcy.

The profitability of an organization can be measured using the Return on Asset (NI/TA) and the Gross Profit Margin (COGS/REV). A company with lower profit levels provides an incentive for the managers to overstate the expenses or revenues, leading to significant financial statement errors [21]. This factor has positive variables as the motivation of fraudulent activities can be measured by checking whether the actual performance meets the posted results.

\section{METHODS}

This research relied on the probability and random sampling methods to help with selecting the fraudulent and non-fraudulent financial reporting firms in the Indonesian 
Agricultural sector. The study involved 21 populations with a sample size of 18 . The research relied on the published financial reporting released by 18 of the chosen companies in the Indonesian Agricultural sector that are listed with the stock exchange as the data collection instruments for each variable.

The dependent variable of the study is fraudulent financial reporting, which is the main cause of the control and the independent variables. Additionally, all the Indonesian Agriculture companies that were listed in the stock exchange for the period 2013-2016. The research will then use the Beneish M-Score as the proxy to help determine whether there is a possibility for a company taking part in fraudulent financial reporting. The Beneish $\mathrm{M}$-score relies on 8 crucial indexes, which include the Total Accruals to Total Assets (TATA), Leverage Index (LVGI), SG\&A Expense Index (SGAI), Depreciation Index (DEPI), Sales Growth Index (SGI), Asset Quality Index (AQI), Gross Margin Index (GMI), and the Days Receivable Index (DSRI).

The financial ratios used in the study serve as independent variables. It is through financial ratios that the interpretation of financial statements is made possible. They include the Return on asset (Ni/TA), the gross profit margin, inventory turnover (IV/TA), receivable turnover (RC/TA), debt to total assets (TD/TA), working capital (WC/TA). The control variables, in this study, include the going concern and the audit quality (dummy variables). The study will then use a multiple regression model to help test the research hypothesis.

\section{RESULTS AND DISCUSSION}

The data was panelled on all estimation models, including the random effects, fixed effects and the applied least squares. This was followed by carrying out a Chow Test, which determines the best model between the Fixed effects or the Pooled least square model. Calculation of the probability values of both the fixed effects and the pooled least square will be conducted by STATA. In STATA, the probability value, which is the output value for the Chow test is Prob>F. The probability values will then be used in the Chow Test to check whether they are greater than or less than F. H1 will be accepted since the p-value (Prob $>\mathrm{F}$ ) is $0.000<$ the alpha 0.05 , making the Fixed Effects Model as the best estimation model for use in this case. Can be seen on table 1 .

TABLE I. FIXED EFFECTS OUTPUT

\begin{tabular}{|c|c|c|}
\hline Variable & p-value & Std. Dev \\
\hline WCTA & 0.009 & 13.62 \\
\hline TDTA & 0.012 & 15.97 \\
\hline RVTA & 0.880 & 1.16 \\
\hline IVTA & 0.875 & $(2.02)$ \\
\hline COGSREV & 0.001 & $(19.20)$ \\
\hline NITA & 0.808 & 1.29 \\
\hline AQ & 0.855 & $(0.46)$ \\
\hline GC & 0.000 & $(10.48)$ \\
\hline Constanta & & 7.10 \\
\hline
\end{tabular}

The regression model is using the Fixed effects model coefficients. Therefore:

MSCORE $=7.10+13.62 \mathrm{WCTA}+15.97 \mathrm{TDTA}+1.16 \mathrm{RV}-$ 2.02 IVTA - 19.20 COGSREV + 1.29 NITA - 0.46 AQ $10.48 \mathrm{G}+\mathrm{e}$

The next step will involve the Hausman Test, to help decide which is the perfect model between the Random effects and the fixed effects model. The probability value will be used to determine whether it is greater than or less than the $F$ value. When carrying out the Hausman test, the STATA output for the probability value (Prob > Chi2) is 0.000 . The fixed-effects model is chosen as the best estimation model as $\mathrm{H} 1$ is accepted since p-value (Prob > Chi2) is $0.000<$ the alpha 0.05 .

The results record a $\mathrm{P}$-value of 0.000 , which is lower than the alpha 0.05, showing that the going concern, Audit quality, ROA, Gross profit margin, Inventory Turnover, receivable turnover, Total debts to total assets and the working capital affect the M-score simultaneously as the proxy for both Nonfraudulent financial reporting and fraudulent financial reporting. The variation recorded by the MSCORE variables affected by the going concern, Audit quality, ROA, Gross profit margin, Inventory Turnover, receivable turnover, Total debts to total assets and the working capital variables within time is at $61.60 \%$, while the other factors left out of this research model account for the remaining $30.40 \%$. On the other hand, the variation recorded by M-SCORE variables affected the going concern, Audit quality, ROA, Gross profit margin, Inventory Turnover, receivable turnover, Total debts to total assets and the working capital between subjects is $44.80 \%$ while all the other factors left out of this research model account for the remaining $55.20 \%$

The variation recorded by M-SCORE variables affected the going concern, Audit quality, ROA, Gross profit margin, Inventory Turnover, receivable turnover, Total debts to total assets and the working capital overall is $2.61 \%$ while all the other factors left out of this research model account for the remaining $97.39 \%$.

TABLE II. M-SCORE RESULTS

\begin{tabular}{|l|l|l|l|l|l|}
\hline \multirow{2}{*}{ No } & \multirow{2}{*}{ Company } & \multicolumn{4}{|c|}{ M-SCORE } \\
\cline { 3 - 6 } & & $\mathbf{2 0 1 6}$ & $\mathbf{2 0 1 5}$ & $\mathbf{2 0 1 4}$ & $\mathbf{2 0 1 3}$ \\
\hline 1 & BISI & $(1,39)$ & $(2,29)$ & $(1,85)$ & $(2,38)$ \\
\hline 2 & AALI & 2,30 & $(1,38)$ & $(1,52)$ & $(2,95)$ \\
\hline 3 & ANJT & $(1,93)$ & $(2,95)$ & $(2,62)$ & $(2,00)$ \\
\hline 4 & DSFI & $(2,03)$ & $(2,16)$ & $(2,29)$ & $(1,55)$ \\
\hline 5 & SGRO & $(2,41)$ & $(2,08)$ & $(2,94)$ & $(2,33)$ \\
\hline 6 & JAWA & $(2,64)$ & $(2,10)$ & $(2,69)$ & $(2,22)$ \\
\hline 7 & LSIP & $(1,96)$ & $(2,03)$ & $(2,92)$ & $(1,71)$ \\
\hline 8 & PALM & $(1,90)$ & $(3,45)$ & $(1,75)$ & $(2,18)$ \\
\hline 9 & SMAR & $(2,28)$ & $(1,33)$ & $(3,08)$ & $(2,98)$ \\
\hline 10 & SSMS & $(2,72)$ & 0,08 & $(1,46)$ & 1,79 \\
\hline 11 & TBLA & $(2,21)$ & $(2,38)$ & $(1,39)$ & $(2,24)$ \\
\hline 12 & UNSP & $(2,49)$ & $(2,66)$ & $(3,06)$ & $(3,88)$ \\
\hline 13 & CPRO & $(4,07)$ & $2,94)$ & $(2,76)$ & $(1,86)$ \\
\hline 14 & IIKP & 23,33 & 0,01 & $(3,38)$ & 1,98 \\
\hline 15 & BTEK & 11,91 & 3,95 & $(2,27)$ & $(3,15)$ \\
\hline 16 & SIMP & $(2,61)$ & $(2,55)$ & $(2,78)$ & $(2,61)$ \\
\hline 17 & BWPT & $(2,64)$ & $(2,14)$ & $(1,92)$ & 0,69 \\
\hline 18 & DSNG & $(2,47)$ & $(2,15)$ & $(2,63)$ & $(2,53)$ \\
\hline
\end{tabular}


Any company with an M-score of less than -2.22 has a lower chance of being a manipulator, however, any of them that records an $\mathrm{M}$-score of greater than -2.22 has a higher likelihood of committing fraud and a manipulator. From the table 2 above, all companies highlighted in red have an $\mathrm{m}$-score that is higher than -2.22 and therefore, likely to engage in fraudulent financial reporting. In the years 2013, 2014, 2015 and 2016, the Indonesian Agricultural sector had 9, 12, 5 and 6 companies respectively, that are likely to be manipulators.

\section{CONCLUSION}

The study relied on 3 different hypotheses, which included the going concern, the audit quality and the working capital ratio. The different results obtained with each hypothesis is different due to different associated theory. It was clear that fraudulent financial reporting is simultaneously affected by both the independent and control variables using the M-score. Other factors not included in the research model could also influence the variation of M-score variables, which is affected by the changes in going concern, audit quality, Gross profit margin, investor turnover, receivable turnover, total debt to total assets and working capital.

This research resents some crucial practical implications for fraud examiners, internal auditors, accounting practitioners and professional accounting bodies. It is belief that the findings of this study will be critical in helping investors make the right investment decisions. Additionally, managers and accounting practitioners can rely on going concern opinion, gross profit margin, total debt to total assets ratio, and working capital in identifying and avoiding incidences of fraud such as fraudulent financial reporting, which can be quite costly to the organization. Finally, managers can also integrate the use of $\mathrm{M}$ scores to help them make management decisions and prevent organizations from becoming bankrupt.

\section{REFERENCES}

[1] R. Kassem and A. Higson, "The new fraud triangle model," J. Emerg. trends Econ. Manag. Sci., vol. 3, no. 3, pp. 191-195, 2012.

[2] O.S. Hutomo and S. SUDARNO, "Cara Mendeteksi Fraudulent Financial Reporting Dengan Menggunakan Rasiorasio Finansial (Studi Kasus Perusahaan Yang Terdaftar di Annual Report BAPEPAM).” Fakultas Ekonomika dan Bisnis, 2012.

[3] O. Persons, "Using financial information to differentiate failed vs. surviving finance companies in Thailand: an implication for emerging economies,” Multinatl. Financ. J., vol. 3, no. 2, pp. 127-145, 1999.
[4] M.S. Beasley, "An empirical analysis of the relation between the board of director composition and financial statement fraud," Account. Rev., pp. 443-465, 1996.

[5] E.H. Feroz, K. Park, and V.S. Pastena, "The financial and market effects of the SEC's accounting and auditing enforcement releases," J. Account. Res., vol. 29, pp. 107-142, 1991.

[6] J.B. Persons and J. Miranda, "Cognitive theories of vulnerability to depression: Reconciling negative evidence,” Cognit. Ther. Res., vol. 16, no. 4, pp. 485-502, 1992.

[7] E.F. Zainudin and H.A. Hashim, "Detecting fraudulent financial reporting using financial ratio,”J. Financ. Report. Account., 2016.

[8] A.S. Omoye and E. Eragbhe, "Accounting ratios and false financial statements detection: evidence from Nigerian quoted companies," Int. J. Bus. Soc. Sci., vol. 5, no. 7, pp. 206-215, 2014.

[9] D.R. Cooper, P.S. Schindler, and J. Sun, "Business research methods," 2003.

[10] K. KPMG, "Malaysia fraud survey report 2009," KPMG, Kuala Lumpur, Malaysia, 2009.

[11] L.E. DeAngelo, “Auditor size and audit quality,” J. Account. Econ., vol. 3, no. 3, pp. 183-199, 1981.

[12] T. O'Keefe and P. Westort, "Conformance to GAAS reporting standards in municipal audits and the economics of auditing: The effects of audit firm size, CPA examination performance, and competition," Res. Account. Regul., vol. 6, no. 1, pp. 39-77, 1992.

[13] T. Hopwood, Accounting as social and institutional practice, vol. 24 Cambridge University Press, 1994

[14] C. Horwath, "Fraud in the Construction Industry: No Company Is Immune, but the Risk Can Be Reduced," 2014. https://www.crowehorwath.com/Website/SiteTemplates/templatemain.aspx?id=7906

[15] S.A.S. AICPA, "No. 99. 2002," Consid. Fraud a Financ. Statement Audit. New York AICPA, 2017

[16] J. Dorminey, A.S. Fleming, M.-J. Kranacher, and R.A. Riley Jr, "The evolution of fraud theory," Issues Account. Educ., vol. 27, no. 2, pp. 555-579, 2012.

[17] Y. Guo, "Audit Quality Control: Big Four Global Member Firms and Audit Services." University of Wyoming. Libraries, 2016.

[18] K.L. Jones, G. V Krishnan, and K. Melendrez, "Do models of discretionary accruals detect actual cases of fraudulent and restated earnings? An empirical evaluation," Contemp. Account. Res. Forthcom., 2006.

[19] N.A. Aris, S.M.M. Arif, R. Othman, and M.M. Zain, "Fraudulent financial statement detection using statistical techniques: The case of small medium automotive enterprise," J. Appl. Bus. Res., vol. 31, no. 4, pp. 1469-1478, 2015.

[20] C.T. Spathis, "Detecting false financial statements using published data: some evidence from Greece," Manag. Audit. J., 2002.

[21] R.W. Kreutzfeldt and W.A. Wallace, "Error characteristics in audit populations-their profile and relationship to environmental-factors," Audit. J. Pract. Theory, vol. 6, no. 1, pp. 20-43, 1986. 